\title{
PELATIHAN DAN PENDAMPINGAN PEMBUATAN VIDEO PEMBELAJARAN MENGGUNAKAN APLIKASI ANDROID DI SEKOLAH DASAR
}

\author{
Karina Wanda ${ }^{1}$, Indah Pratiwi ${ }^{2}$, Chairunnisa Amelia ${ }^{3}$ \\ ${ }^{1,2,3)}$ Program Studi PGSD, FKIP, Universitas Muhammadiyah Sumatera Utara \\ e-mail:karinawanda@umsu.ac..id,indahpratiwi@umsu.ac.id,chairunnisaamelia@umsu.ac.id
}

\begin{abstract}
Abstrak
Judul kegiatan Program Kemitraan Masyarakat (PKM) yang diusulkan adalah "Pelatihan dan Pendampingan Pembuatan Video Pembelajaran Menggunakan Aplikasi Android di Sekolah Dasar. Kegiatan ini dilaksanakan dalam rangka menyambut semakin berkembangnya model-model pembelajaran yang dapat diterapkan dalam mengajar sehari-hari. Selain itu guru juga dituntut dapat beradaptasi dengan kondisi dan situasi Pandemi Covid-19 dalam menerapkan model pembelajaran yang bervariasi. Kegiatan dalam pelatihan ini adalah guru-guru dari kedua sekolah yaitu SD Negeri 027977 Binjai dan SD Negeri 024183 Binjai yang akan diberikan pelatihan dan pendampingan dalam Pembuatan Video Pembelajaran Menggunakan Aplikasi Android mulai dari mendowload aplikasi di android kemudian menyiapkan model pembelajaran yang digunakan, konten pembelajaran, pengambilan data yang digunakan untuk pembelajaran kelas daring dan juga bahan ajar apa yang akan digunakan dalam membuat video pembelajaran. Guru juga akan diberikan Video Tutorial Youtube pembuatan video pembelajaran yang berisikan model- model pembelajaran yang dapat digunakan dan diterapkan menggunakan video pembelajaran dalam mengajar daring.
\end{abstract}

Kata Kunci : Pelatihan, Video Pembelajaran, Guru Sekolah Dasar

\begin{abstract}
The title of the proposed Community Partnership Program (PKM) activity is "Training and Assistance in Making Learning Video Video Pembelajaran Using Android Applications in Elementary Schools. This activity is carried out in order to welcome the growing development of learning models that can be applied in daily teaching. In addition, teachers are also required to be able to adapt to the conditions and situations of the COVID-19 pandemic in applying varied learning models. Activities in this training are teachers- teachers from both schools, namely SD Negeri 027977 Binjai and SD Negeri 024183 Binjai who will be given training and assistance in Making Learning Video Video Pembelajaran Using Android Applications starting from downloading applications on android then preparing the learning model used, learning content, data collection used for learning online classes and also what teaching materials will be used in making learning video Video Pembelajaran. Teachers will also be given a guidebook for making learning video Video Pembelajaran that contains learning models that can be used and applied using instructional video Video Pembelajaran in online teaching.
\end{abstract}

Keywords: Training, Video Pembelajaran, Elementary School Teachers

\section{PENDAHULUAN}

Menurut Undang-Undang Guru dan Dosen Nomor 14 Tahun guru professional dituntut memenuhi empat kompetensi pokok, yakni: 1) pedagogi, 2) professional, 3) sosial, dan 4) pribadi. Dari empat kompetensi ini, dapat diidentifikasi beberapa kompetensi utama yang wajib dimiliki guru, yakni adalah: (1) mengembangkan kurikulum yang terkait dengan bidang pembelajaran yang diampu, (2) menyelenggarakan kegiatan pembelajaran yang mendidik, (3) mengembangkan materi pembelajaran yang diampu secara kreatif dan (4) memanfaatkan teknologi informasi dan komunikasi untuk berkomunikasi dan mengembangkan diri. UU ini, disusul dengan Peraturan Pemerintah Nomor 19 tahun 2006 tentang standarisasi pendidikan..

Melalui UU dan Peraturan di atas, guru tidak hanya mengajar. Guru dituntut melakukan langkah-langkah strategis untuk meningkatkan kualitas dirinya dan secara otomatis kualitas pembelajarannya. Fungsi dan peran guru, dengan demikian, juga menjadi berubah. Dengan nalar di 
atas, langkah-langkah yang harus dilakukan guru adalah sebagai berikut: 1). Melaksanakan pengembangan diri melalui kegiatan diklat fungsional dan kegiatan kolektif guru; 2). Pelaksanaan karya inovatif penemuan penelitian tepat guna, penemuan/penciptaan atau pengembangan karya seni, 3.)pembuatan/pemodifikasian alat peraga, penyusunan standar dan pedoman.

Pengakuan atas profesi guru memiliki konsekuensi logis yang penting bagi guru. Salah satu konsekuensi logis itu adalah bahwa guru dituntut untuk selalu memperbarui atau mengembangkan dirinya. Secara lebih luas, guru dituntut untuk selalu mengembangkan keprofesiannya secara terus menerus, misalnya melalui pendidikan dan pelatihan, pengembangan bahan ajar dan alat peraga, dan sebagainya. Kegiatan pengembangan bahan ajar dan alat peraga umumnya merupakan suatu hal yang tidak mudah untuk dilakukan oleh guru. Ironisnya lagi, terkadang pengembangan bahan ajar dan alat peraga terkhusus video pembelajaran pembelajaran berbasis video ini digunakan ketika hanya ada stakeholder yang menyediakannya. Pada sisi lain tuntutan dan tantangan yang dihadapi guru dalam melaksanakan tugas profesinya makin beragam dan berat apalagi disaat pandemic covid saat ini proses belajar mengajar dilaksanakan secara daring. Seperti layaknya seorang dokter, bahkan dokter spesialis, guru pun dituntut untuk mampu memecahkan berbagai permasalahan yang dihadapinya dalam kaitan dengan pengelolaan pendidikan dan pembelajaran di sekolah. Sementara itu, kondisi Pandemi Covid-19 dan perkembangan ilmu pengetahuan dan teknologi (IPTEK) demikian pesatnya dewasa ini. Guru ditantang untuk selalu dapat mengikuti perkembangan iptek itu jika tidak ingin 'tergilas oleh waktu' dan sistem belajar mengajar saat Pademi Covid-19. Tuntutan atau tantangan profesi dan perubahan kondisi saat ini harus dapat dijawab guru melalui tindakan nyata yang berawal dari pribadi guru itu sendiri. Oleh karena itu, pengembangan keprofesian guru menjadi sebuah keniscayaan.

Salah satu upaya yang cukup menjanjikan bagi pengembangan materi pembelajaran guru itu adalah melakukan kegiatan mengembangkan materi pembelajaran yang diampu secara kreatif dan (4) memanfaatkan teknologi informasi dan komunikasi untuk berkomunikasi dan mengembangkan diri. melalui video pembelajaran pembelajaran berbasis video ini, guru dapat melakukan sekaligus minimal tiga hal, yaitu mampu beradaptasi, mempunyai skills, dan mengembangkan keprofesian secara berkelanjutan. muslich (2009) mengatakan bahwa Video Pembelajaran pembelajaran berbasis video menawarkan peluang strategi pengembangan kinerja melalui pemecahan masalah-masalah pembelajaran (teaching-learning problem solving), sebab pendekatan dalam video pembelajaran pembelajaran berbasis video menempatkan guru sebagai pendidik sekaligus sebagai agen perubahan. melakukan video pembelajaran pembelajaran berbasis video bahkan sangat disarankan beberapa pakar karena nilai manfaat dari kegiatan Video Pembelajaran pembelajaran berbasis video itu sangat besar, baik bagi guru sendiri maupun bagi pendidikan dan pembelajaran, siswa, dan sekolah. Wiriaatmadja (2008) mengatakan bahwa jawaban paling utama terhadap pertanyaan mengapa guru harus melakukan video pembelajaran pembelajaran berbasis video ialah untuk mengubah citra dan meningkatkan keterampilan profesional guru. dengan kata lain, dapat dikatakan bahwa video pembelajaran pembelajaran berbasis video merupakan sebuah pilihan solutif bagi guru untuk membantu memecahkan berbagai persoalan pembelajaran dan/atau pendidikan yang dikelolanya di samping untuk membantu mengembangkan keprofesian guru secara berkelanjutan.

Peraturan menteri pendidikan nasional Nomor 16 tahun 2007 tentang standar kualifikasi akademik dan kompetensi guru a.l. mengatur tentang kompetensi guru. pada kompetensi pedagogik terdapat kompetensi inti guru. salah satu kompetensi inti guru itu adalah melakukan tindakan reflektif untuk peningkatan kualitas pembelajaran. kompetensi inti guru ini dijabarkan menjadi kompetensi guru, salah satunya adalah mampu membuat Video Pembelajaran pembelajaran kompetibel dengan situasi saat ini untuk meningkatkan kualitas pembelajaran. hal ini berarti bahwa melakukan video pembelajaran pembelajaran berbasis video merupakan bagian penting tuntutan standar kompetensi yang harus dicapai guru.

Hopkins (dalam kunandar, 2008) memberikan batasan tentang Video Pembelajaran pembelajaran berbasis video sebagai "suatu bentuk penyelidikan refleksi diri yang dilakukan oleh peserta dalam situasi sosial (termasuk pendidikan) untuk meningkatkan rasionalitas dan keadilan: (a) praktik sosial atau pendidikan mereka sendiri; (b) pemahaman mereka tentang praktik-praktik ini; dan (c) situasi di mana praktik dilakukan." dalam konteks pendidikan, hal di atas mengandung pengertian bahwa video pembelajaran pembelajaran berbasis video merupakan suatu bentuk 
refleksi diri yang dilakukan pendidik untuk mengembangkan rasionalitas terhadap pelaksanaan praktik pendidikan atau pembelajaran dan memperdalam pemahaman terhadap kondisi pelaksanaan praktik pendidikan atau pembelajaran.

Kemmis dan MC. Taggart (dalam muslich, 2009) mengemukakan bahwa video pembelajaran pembelajaran berbasis video merupakan studi untuk memperbaiki diri sendiri atau pengalaman kerja sendiri yang dilaksanakan secara sistematis, terencana, dan mawas diri. berdasarkan pandangan-pandangan di atas, dapat dikatakan bahwa video pembelajaran pembelajaran berbasis video merupakan suatu bentuk penelitian praktis yang dilakukan pendidik untuk merefleksikan tindakan yang dilaksanakan dalam rangka memperbaiki praktik pembelajaran atau pendidikan.

Terdapat beberapa prinsip yang perlu diperhatikan oleh guru (peneliti) dalam pelaksanaan Video Pembelajaran pembelajaran berbasis video. pada modul membimbing guru dalam penelitian tindakan kelas (materi pelatihan penguatan kemampuan pengawas sekolah tahun 2010), yang dikeluarkan oleh direktorat tenaga kependidikan, beberapa prinsip Video Pembelajaran pembelajaran berbasis video adalah sebagai berikut. pertama, tindakan dan pengamatan dalam proses penelitian yang dilakukan tidak boleh mengganggu atau menghambat kegiatan utama, misalnya bagi guru tidak boleh sampai mengorbankan kegiatan pembelajaran. kedua, masalah penelitian yang dikaji merupakan masalah yang cukup merisaukan dan berpijak dari tanggung jawab profesional guru. ketiga, metode pengumpulan data yang digunakan tidak menuntut waktu yang lama sehingga berpeluang menggangu proses pembelajaran. keempat, metodologi yang digunakan harus terencana secara cermat sehingga tindakan dapat dirumuskan dalam suatu hipotesis tindakan yang dapat diuji di lapangan. kelima, permasalahan atau topik yang dipilih harus benar-benar nyata, menarik, mampu ditangani, dan berada dalam jangkauan kewenangan peneliti untuk melakukan perubahan. keenam, peneliti harus tetap memperhatikan etika dan tata krama penelitian serta rambu-rambu pelaksanaan yang berlaku umum. ketujuh, kegiatan Video Pembelajaran pembelajaran berbasis video pada dasarnya merupakan kegiatan yang berkelanjutan karena tuntutan terhadap peningkatan dan pengembangan akan menjadi tantangan sepanjang waktu. kedelapan, meskipun kelas atau mata pelajaran merupakan tanggung jawab guru, namun tinjauan terhadap Video Pembelajaran pembelajaran berbasis video tidak terbatas dalam konteks kelas dan atau mata pelajaran tertentu melainkan dalam perspektif misi sekolah. kita dapat memulai Video Pembelajaran pembelajaran berbasis video dari permasalahan yang kita temui atau hadapi dalam mengelola pembelajaran.

Dalam PKM yang diusulkan ini, guru-guru dari 2 sekolah mitra yaitu SDN 027977 Binjai dan SDN 024183 Binjai, akan diberi pelatihan dan pendampingan pembuatan Video Pembelajaran pembelajaran berbasis video dengan menggunakan Video Tutorial Youtube model - model pembelajaran. berdasarkan dasar pemikiran tentang video pembelajaran pembelajaran berbasis video diatas, penguatan kompetensi sdm guru - guru di sekolah mitra UMSU perlu mendapat perhatian civitas akademika di lingkungan umsu mempunyai tanggung jawab oral ikut mengembangkan sekolah binaan yang merupakan bagian dari amal usaha Muhammadiyah untuk meningkatkan kualitas tenaga pendidik atau guru setempat.

\section{METODE}

\section{Khalayak Sasaran}

Khalayak sasaran pengabdian masyarakat ini tentu saja adalah guru di SD Negeri 027977 Binjai dan SD Negeri 024183 Binjai. khalayak sasaran diutamakan seluruh guru Pegawai Negeri Sipil (PNS) dan pegawai honor di dua sekolah tersebut yang berjumlah 25 orang. melalui kegiatan ini diharapkan khalayak sasaran dapat menerapkan IPTEK dalam bentuk membuat Video Pembelajaran pembelajaran berbasis video dengan menggunakan aplikasi android.

\section{Metode Kegiatan}

Pendampingan dalam bentuk pelatihan dan workshop pembuatan video pembelajaran pembelajaran berbasis video dengan menggunakan aplikasi android video pembelajaran pembelajaran berbasis video yang akan dibuat oleh guru diupayakan dapat meningkatkan hasil belajar siswa dengan menggunakan model - model pembelajaran di kelas dan dapat meningkatkan sasaran kinerja guru - guru tersebut. 


\section{Langkah - Langkah Kegiatan}

Pelaksanaan program kemitraan masyarakat ini dilakukan dengan tiga tahapan, dimana tahap pertama merupakan tahapan persiapan. pada tahap ini kelompok pengabdian masyarakat melakukan survey pendahuluan untuk melihat kondisi di lapangan mengenai sarana dan prasarana serta kompetensi guru dalam mengajar daring. tahap selanjutnya merupakan tahapan pelaksanaan kegiatan program. dalam tahap ini tim akan melakukan kegiatan pelatihan dan pendampingan pembuatan Video Pembelajaran pembelajaran berbasis video. dalam tahap pelaksanaan ini kelompok pengabdian masyarakat memberikan pelatihan membuat video pembelajaran pembelajaran berbasis video dan juga memberikan guru - guru tersebut Video Tutorial Youtube model - model pembelajaran berbasis video menggunakan aplikasi android yang akan menjadi referensi guru dalam membuat Video Pembelajaran pembelajaran berbasis video. Guru - guru juga dipandu dari setiap masing - masing bab yang ada pada draft video pembelajaran pembelajaran berbasis video. Tahap yang terakhir adalah tahap evaluasi. pada tahap ini dilakukan evaluasi atas hasil yang telah dicapai oleh peserta pelatihan. masukan dan perbaikan lebih lanjut dapat dilakukan pada tahap ini. evaluasi diberikan dengan mengumpulkan data yang diperoleh dari kegiatan pelatihan. data diambil dengan menyimpulkan pemahaman guru - guru ketika membuat video pembelajaran pembelajaran berbabasis video. Indikator ketercapaian tujuan program kemitraan ini adalah bahwa $80 \%$ guru - guru sudah memahami dan dapat membuat video pembelajaran pembelajaran berbasis video dan melihat hasil proses belajar mengajar pada kelasnya masing masing. adapun langkah - langkah kegiatan ini dapat dijelaskan sebagai berikut :

\section{Langkah 1 :}

Peserta pelatihan diminta mendownload aplikasi inShot kemudian diberikan materi tentang membuat Video Pembelajaran pembelajaran berbasis video menggunakan aplikasi android.

\section{Langkah 2 :}

Peserta diberikan kesempatan untuk mendiskusikan materi yang telah diberikan. Kesempatan tanya jawab cara pembuatan dan pengeditan video diberikan untuk memperjelas hal-hal yang masih menjadi keraguan.

\section{Langkah 3 :}

peserta berlatih untuk membuat Video Pembelajaran pembelajaran berbasis video

\section{Langkah 4 :}

Peserta melakukan penelitian dengan langsung menguji coba menggunakan dikelasnya masing masing untuk melihat peningkatan hasil belajar siswa dengan menggunakan model pembelajaran yang bervariasi.

\section{Langkah 5 :}

peserta melakukan presentasi video pembelajaran pembelajaran berbasis video

\section{Langkah 6 :}

Hasil karya peserta dikumpulkan dan dianalisis untuk diberikan masukan dan perbaikan lebih lanjut.

\section{HASIL DAN PEMBAHASAN}

\section{Kegiatan Koordinasi Awal}

Pelaksanaan kegiatan program kemitraan masyarakat PKM ini dilaksanakan di SD Negeri 027977 Binjai dan SD Negeri 024183 Binjai. Pada pra- kegiatan tim PKM mengadakan perencanaan dengan mengunjungi untuk melakukan wawancara untuk kegiatan PKM ini dengan kepala sekolah SD Negeri 027977 Binjai, dan kepala sekolah SD Negeri 024183 Binjai.

Berdasarkan hasil wawancara dan fakta-fakta dilapangan, banyak ditemukan guru masih menggunakan Video Pembelajaran pembelajaran konvensional, yaitu Video Pembelajaran pembelajaran yang tersedia dan dilakukan tanpa adanya perencanaan, menyiapkan bahan dan menyusunnya sediri. Hal ini tentunya akan berdampak pada kemampuan siswa, pembelajaran menjadi tidak menarik, bersifat monoton dan tidak sesuai dengan kebutuhan siswa.

Dengan adanya permasalah yang muncul tersebut, ada beberapa yangdisepakati, antara lain yaitu, (1) Jenis Video Pembelajaran yang akan diberikan pelatihan kepada para guru, maka jenis Video Pembelajaran yang akan dilatihkan kepada guru yaitu Video Pembelajaran berbasis Media Video Pembelajaran Menggunakan Aplikasi Android. Pemilihan Video Pembelajaran berbasis Media Video Pembelajaran Menggunakan Aplikasi Android karena Video Pembelajaran 
merupakan aplikasi professional dalam membuat video. Video Pembelajaran termasuk Video Pembelajaran yang digunakan oleh para guru professional dalam era revolusi industri 4.0, (2) Jadwal pelaksanaan pengabdian; berdasarkan kesepakatan pelaksanaan pengabdian masyarakat akandilaksanakan pada bulan Juli namun karena kondisi masih dalam suasana pandemi Covid-19, maka kegiatan ini diundur dan dilaksanakan pada hari senin 22 Juli 2020. Kegiatan PKM ini dilaksanakan di SD Negeri 027977 Binjai yang diikuti oleh 24 guru dari dua sekolah yang setiap sekolah mengirimkan 12 guru dari perwakilan setiap kelas serta melibatkan 2 mahasiswa.

\section{Persiapan Pelatihan dan Pendampingan Video Pembelajaran Berbasis Media Video Pembelajaran Menggunakan Aplikasi Android}

Kegiatan pengabdian masyarakat yang berjudul "Pelatihan dan Pendampingan Video Pembelajaran Berbasis Media Video Pembelajaran Menggunakan Aplikasi Android bagi guru SD Muhammadiyah Kota Medan" bertujuan untuk mengembangkan kompetensi gurudalam mengajar di dalam kelas dengan menggunakan Video Pembelajaran berbasis Media Video Pembelajaran Menggunakan Aplikasi Android. Media Video Pembelajaran Menggunakan Aplikasi Android merupakan aplikasi professional dalam mendesain video Pembelajaran yang dapat menciptakan pembelajaran yang kreatif dan menyenagkan.

Tim PKM menyiapkan master Media Video Pembelajaran Menggunakan Aplikasi Android untuk dibagikan kepada guru supaya dapat diinstal di laptopnya masing- masing dan membagikan video tutorial youtube pembuatan Video Pembelajaran berbasis Media Video Pembelajaran Menggunakan Aplikasi Android yang sebelumnya telah disusun oleh tim PKM. Sementara itu, mitra PKM SD Negeri 027977 Binjai menyediakan ruangan untuk kegiatan pengabdian serta peralatan seperti infokus. Ruangan yang digunakan adalah salah satu kelas yang telah dilengkapi infokus untuk menampilkan tutorial pembuatan Video Pembelajaran berbasis Media Video Pembelajaran Menggunakan Aplikasi Android.

Video tutorial youtube dalam pelatihan dan pendampingan ini disusun berdasarkan kebutuhan dalam membuat Video Pembelajaran berbasis Media Video Pembelajaran Menggunakan Aplikasi Android. Tahapan dalam penyusunan video tutorial youtube ini yaitu:

Perencanaa, di dalam perencanaan ini ada beberapa langkah yang dilakukan yaitu (1) Merumuskan tujuan umum dan khusus. Tujuan umum dalam pembuatan video tutorial youtube ini adalah guru dapat mengikuti setiap langkah yang ada dapan video tutorial youtube ini dalam membuat Video Pembelajaran berbasis Media Video Pembelajaran Menggunakan Aplikasi Android, sedangkan tujuan khususnya guru dapat berkreasi dalam membuat Video Pembelajaran yang menarik dan mendorong siswa dapat aktif dalam pembelajaran;

(2) Pemetaan konsep video tutorial youtube. Pemetaan konsep Video Tutorial Youtube digunakan oleh penulis untuk memberikan gambaran/alur dari video tutorial youtube yang akan dihasilkan; (3) Menentukan bentuk Video Pembelajaran yang dihasilkan. Penting menentukan bentuk Video Pembelajaran yang akan dihasilkan berdasarkan Video Tutorial Youtube ini sebab tampilan da nisi serta aksesoris Video Pembelajaran akan mendukung pembelajaran lebih diminati oleh siswa.

Persiapan, pada langkah persiapan inivideo tutorial youtube akan dirancang sebagai berikut: (1) mengurutkan ide. Menjabarkan materi- materi yang telah disusun berdasarkanpemetaan konsep dari Video Tutorial Youtube ; (2) mempertimbangkan sumber-sumber yang mendukung. Keakuratan informasi yang dibutuhkan dalam membuat video tutorial youtube ini menjadi unsur yang harus dipertimbangkan; (3) menentukan desain grafis. Desain grafis yang menarik akan membuat pembaca menjadi tertarik untuk mempelajari Video Tutorial Youtube tersebut; (4) menentukan komponen fisik video tutorial youtube. Komponen fisik dari video tutorial youtube ini terdiri dari Video Tutorial Youtube.

Perancangan, membuat rancangan awal video tutorial youtube (prorotype). Berikut ini Video Tutorial Youtube yang telah dirangcang oleh penulis: 


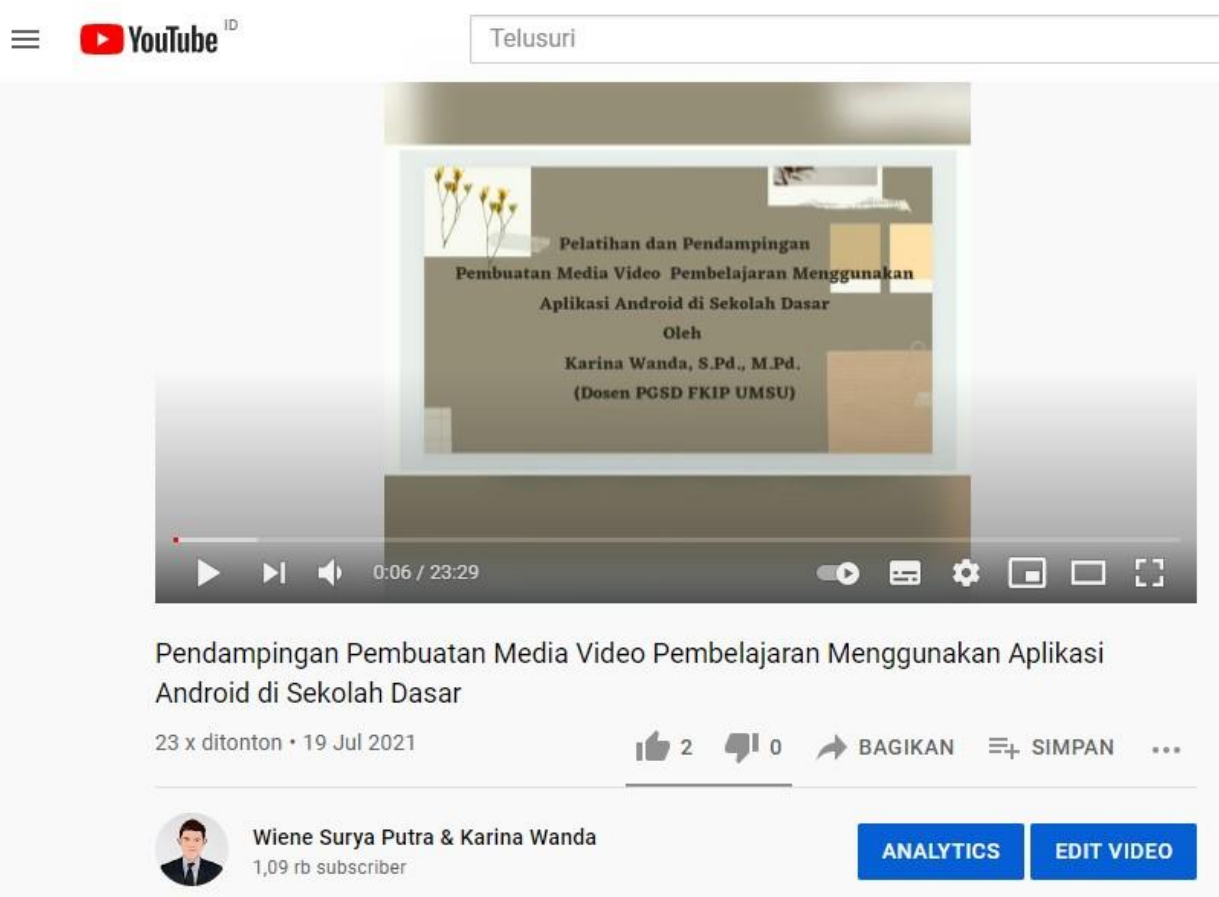

Gambar 1. Video tutorial youtube Pembuatan Video Pembelajaran Video Pembelajaran Menggunakan Aplikasi Android

Berdasarkan Video Tutorial Youtube di atas, akan dihasilkan sebuah Video Pembelajaran pembelajaran berbasis Media Video Pembelajaran Menggunakan Aplikasi Android.

\section{Pelaksanaan Pengabdian}

Pengabdian dilaksanakan kepada guru-guru berupa pelatihan dan pendampingan pembuatan Video Pembelajaran berbasis Media Video Pembelajaran Menggunakan Aplikasi Android yang kreatif dan menyenangkan bagi siswa. Melalui kegiatanini, akan membuka wawasan guru bahwa banyak aplikasi yang dapat digunakan untuk membuat Video Pembelajaran danmengembangkan keterampilan guru dalammenyajikan pembelajaran yang menarik bagi siswa dengan menggunakan Video Pembelajaran berbasis Media Video Pembelajaran Menggunakan Aplikasi Android. Selain itu, dengan adanya keterampilan tersebut, masyarakat sasaran memiliki kesempatan menciptakan proses pembelajaran yang lebih menarik dan efektif; dapat mengembangkan Video Pembelajaran pembelajaran yang kreatif dan inovatif untuk mendorong motivasi, perkembangan kognisi, perkembangan interpersonal danperkembangan aspek sosial yang dimiliki.Rahmawati et al. (2017) menyatakan bahwa penggunaan teknologi dalam pembelajaran dapat meliputi berbagai hal yang berkaitan dengan proses, alat bantu, manipulasi dan pengelolaan informasi

Keberhasilan kegiatan PKM ini dapat diukur dan dilihat dengan mengamati kinerja para guru yang mempu membuat sendiri Video Pembelajaran berbasis Media Video Pembelajaran Menggunakan Aplikasi Android. Selain itujuga, dengan adanya indikator pencapaian yang telah ditetapkan bahwa pengabdian ini dinyatakan berhasil apabila guru sudahmemiliki minimal 1 Video Pembelajaran berbasis Media Video Pembelajaran Menggunakan Aplikasi Android untuk dapat digunakan di dalam kelas. Pengembangan Video Pembelajaran berbasis Media Video Pembelajaran Menggunakan Aplikasi Android yang sukses dibuat oleh para guru dapat diimplementasikan pada tema-tema yang berbeda yang terdapat di dalam kurikulum 2013. Selain itu juga dapat meningkatkan life skill guru (Nugraheny et al., 2018)

Berdasarkan hasil pelaksanaan PKM ini terdapat 10 guru yang mampu membuat Video Pembelajaran pembelajaran berbasis Media Video Pembelajaran Menggunakan Aplikasi Android atau $83,33 \%$ guru yang mampu membuat Video Pembelajaran pembelajaran berbasis Video Pembelajaran

Android dengan berbagai revisi. Dan terdapat 2 orang guru atau 16,66\% belum mampu membuat Video Pembelajaran pembelajaran menggunakan Media Video Pembelajaran Menggunakan Aplikasi Android. Hal ini terjadi karena guru masih kesulitan menggunakan teknologi dan masih 
pertama sekali menggunakan Media Video Pembelajaran Menggunakan Aplikasi Android sebagai aplikasi pembuatVideo Pembelajaran pembelajaran.

Media Video Pembelajaran Menggunakan Aplikasi Android ini berhasil membuka wawasan guru dan mengembangkankemampuan guru dalam membuat Video Pembelajaran pembelajaran di SD Muhammadiyah Kota Medan. Para guru telah mampu mengembangkan Video Pembelajaran dengan menggunakan Media Video Pembelajaran Menggunakan Aplikasi Android denga berbagai tema yang terdapat dalam kurikulum 2013. Untuk itu kegiatan ini dapat memberikan manfaat dalam meningkatkan mengembangkan kemampuan guru, kreativitas dan kesadaran pentingnya Video Pembelajaran dalam pembelajaran.

Dalam pelaksanaan pengabdian ini, ada beberapa kendala yang dihadapi oleh tim PKM diantaranya HP yang dimiliki oleh guru terkadang kurang canggih saat penginstalan software Media Video Pembelajaran Menggunakan Aplikasi Android, guru belum memiliki kemampuan digital yang baik sehingga perlu dilatih.

Berikut tim pengabdian memberikan pelatihan dan pendampingan kepada mitra dalam pembuatan Video Pembelajaran pembelajaran berbasis Media Video Pembelajaran Menggunakan Aplikasi Android

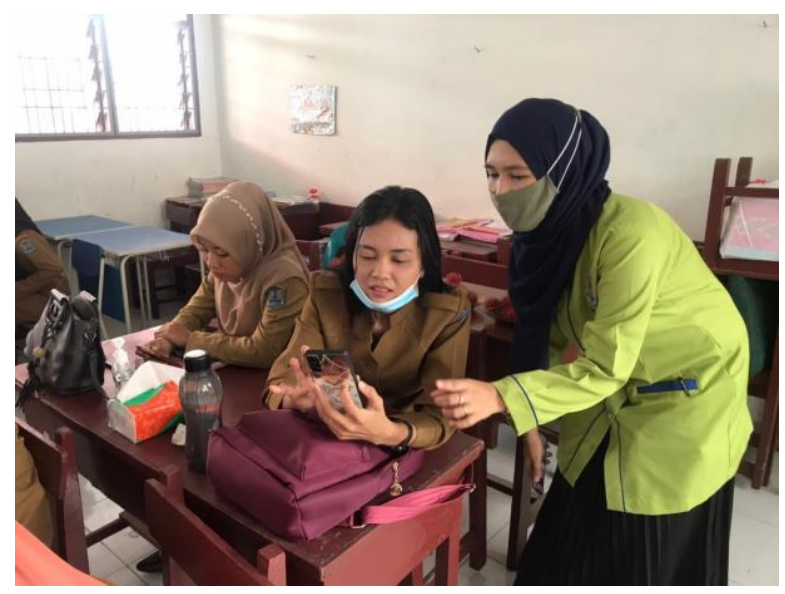

Gambar 2. Pendampingan Guru Membuat Video Pembelajaran Pembelajaran Berbasis Media Video Pembelajaran Menggunakan Aplikasi Android

\section{SIMPULAN}

Untuk keberlanjutan kegiatan PKM ini perlu juga perhatian dari segala pihak terutamaBapak kepala sekolah selaku supervisor sekolah untuk mengontrol dan mengawasi guru dalam menggunakan Video Pembelajaran berbasis Media Video Pembelajaran Menggunakan Aplikasi Android dan dikarenakanketerbatasan waktu juga tidak banyak materi yang tersampaikan ditambah lagi guru barupertama kalinya menggunakan Media Video Pembelajaran Menggunakan Aplikasi Android sebagai Video Pembelajaran. Program Kepada Masyarakat (PKM) melalui pelatihan dan pendampinganpembuatan Video Pembelajaran berbasis Android.

\section{UCAPAN TERIMA KASIH}

Ucapan terima kasih kami sampaikan kepada:

a. Rektor Universitas Muhammadiyah Sumatera Utara atas izin dan pembinaannya sehingga kegiatan Tri Dharma Perguruan Tinggi ini terlaksana dengan baik.

b. Ketua Lembaga Penelitian dan Pengabdian kepada Masyarakat (LP2M) Universitas Muhammadiyah Sumatera Utara atas dukungan dan arahannya.

c. Kepala Sekolah dan Guru-Guru SD Negeri 027977 Binjai

d. Kepala Sekolah dan Guru-Guru SD Negeri 024183 Binjai

e. Seluruh anggota tim pelaksana kegiatan pelatihan atas kerjasamanya yang baik.

f. Seluruh pihak yang telah berpartisipasi dalam kegiatan pelatihan ini yang tidak dapat kami sebutkan satu persatu. 


\section{DAFTAR PUSTAKA}

Nurgayah. (2011). Strategi Dan Metode Pembelajaran. Cita Pustaka.

Rahmaibu, F. H., Ahmadi, F., \& Prasetyaningsih, F. D. (2017). Pengembangan Video Pembelajaran Pembelajaran Menggunakan Adobe Android Untuk Meningkatkan Hasil Belajar PKn.Jurnal Kreatif : Jurnal Kependidikan Dasar, 7(1).

Rahmawati, F., Haryanto, \& Alamsyah. (2017).Pelatihan Model Pembelajaran Berbasis Teknologi Informasi Dan Komunikasi Bagi Guru SMP Negeri 2 Jati Agung Lampung Selatan. Adiguna: Jurnal Pengabdian DanPemberdayaan Masyarakat, 2(2), 20-24.

Sani, A. R. (2014). Pembelajaran Saintifik Untuk Implementasi Kurikulum 2013 (Y. S. Hartati (ed.)). Bumi Aksara.

Sari, H. L., \& Negara, E. K. (2011). Video Pembelajaran Pembelajaran Kimia Terpadu Pada Madrasah Tsanawiyah Negeri (MAN) 2 Kota Bengkulu. Jurnal Video Pembelajaran Infotama, $7(2), 103-120$.

Surachman, E. (2013). WorkshopPemanfaatan Video Pembelajaran Pembelajaran Sebagai Upaya Peningkatkan Efektifitas Pembelajaran Serta Profesionalitas Pendidik Di SMP Negeri 194 Jakarta. Jurnal Sarwahita, 13(2), 111-119. https://doi.org/DOI https://doi.org/10.21009/sarwahita.132.06

Tri, S., \& Atika, N. H. (2018). Penggunaan danPemanfaatan Teknologi Informasi dan Komunikasi (P2TIK) Sektor Pendidikan2018.

Umbara, U., Rosyid, A., \& Setiawan, D. L. (2019). Pelatihan Pembuatan Video Pembelajaran Pembelajaran Matematika BerbasisAndroid Menggunakan Adobe Animatebagi Guru SMP di KabupatenKuningan. Jurnal Pengabdian PadaMayarakat, 4(1), 93104.https://doi.org/10.30653/002.201941.84

Ali, M. (2018). Media Video Pembelajaran Menggunakan Aplikasi Android Untuk Inovasi Pengajaran Matematika Dan Sains SDN Kota Baubau. Jurnal Pengabdian Kepada Masyarakat MEMBANGUN NEGERI, 2(2), 85-93.

Angraini, L. M., Sudiarta, I. W., Qomariyah, N., Alaa, S., \& Handayana, I. G. N. Y. (2019). Peningkatan Kompetensi Komputasi Fisika Dan Kimia Untuk Mahasiswa Program Studi Fisika FMIPA Universitas Mataram. SELAPARANG. Jurnal Pengabdian Masyarakat Berkemajuan, 2(3), 37-41.

Kartimi, Mulyani, A., \& Riyanto, O. R. (2019). Pemberdayaan Guru Dalam Implementasi Pembelajaran Abad 21. DIMASEJATI, 1(2), 160-170.

Mulyono, A. (2009). Pendidikan Bagi Anak Kesulitan Belajar. Rineka Cipta.

Nugraheny, D., Wintolo, H., Kusum, A., \& Sudaryanto. (2018). Pendampingan Pembuatan Bahan Ajar Berbasis MultiVideo Pembelajaran Menggunakan Media Video Pembelajaran Menggunakan Aplikasi Android Bagi Para Guru SD IT Salsabila Al Muthi' in, Yogyakarta. Jurnal Pengabdian Mayarakat BidangTeknologi, KACANEGARA, 1(1), 23-28. 